\title{
Budget Transparency in Croatian Counties, Cities and Municipalities: November 2020 - April 2021
}

Bronić, Mihaela; Opačak, Marija; Ott, Katarina; Petrušić, Miroslav; Stanić, Branko

Source / Izvornik: IPF Notes, 2021, 14, 1 - 11

Journal article, Published version

Rad u časopisu, Objavljena verzija rada (izdavačev PDF)

https://doi.org/10.3326/in.2021.119

Permanent link / Trajna poveznica: https://urn.nsk.hr/urn:nbn:hr:242:123599

Rights / Prava: Attribution-NonCommercial-NoDerivatives 4.0 International/ImenovanjeNekomercijalno-Bez prerada 4.0 međunarodna

Download date / Datum preuzimanja: 2023-04-26

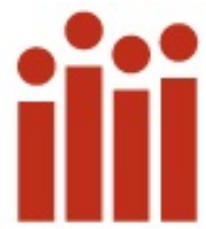

Repository / Repozitorij:

Institute of Public Finance Repository

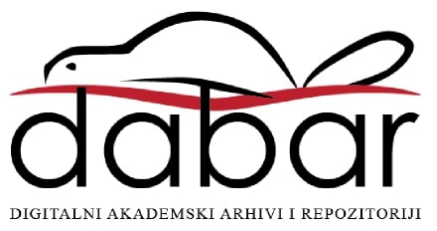




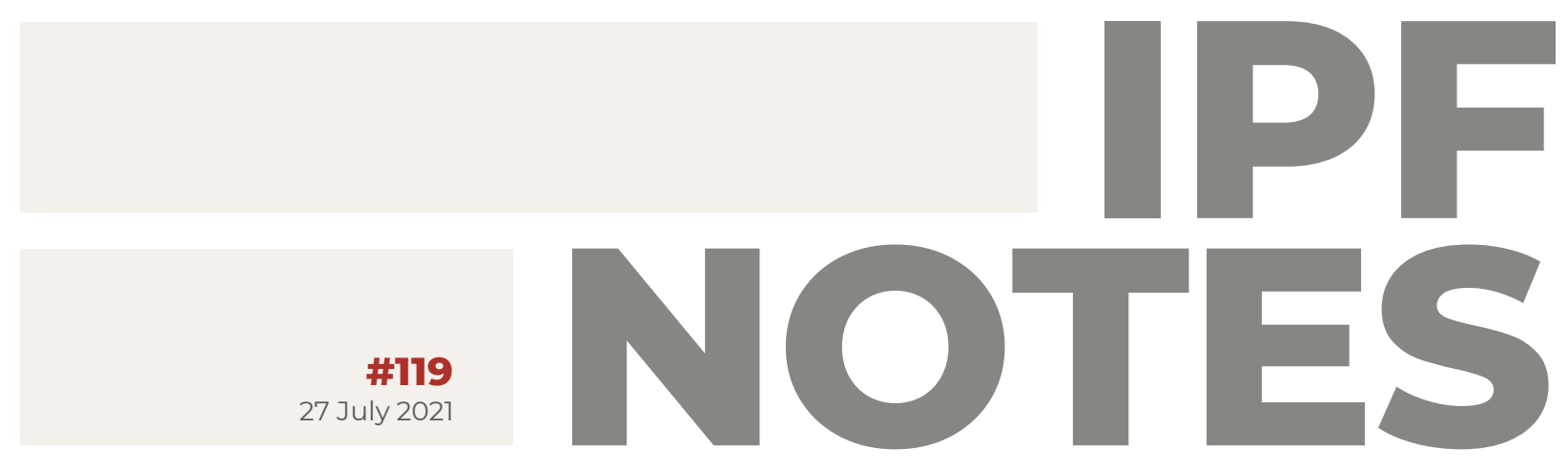

\title{
Budget Transparency in
} Croatian Counties, Cities and Municipalities: November 2020 - April 2021

\author{
Mihaela Bronić, Marija Opačak, Katarina Ott, \\ Miroslav Petruöić, Branko Stanić \\ Institut za javne financije, Zagreb
}

The average level of budget transparency in all Croatian local government units, expressed as the number of key budget documents published on their respective official websites, stands at 4.5 (out of a maximum 5). All counties published all five requested budget documents, cities published 4.7 documents on average, while municipalities' average score stands at 4.4. However, despite high average rates, $8 \%$ of cities (10) and 16\% of municipalities (68) still fail to publish all three documents required by law, while 20\% of cities and 31\% of municipalities fail to publish the two documents whose publication was recommended by the Ministry of Finance. Although the publishing of key budget documents does not in itself signify absolute transparency, it is considered the initial step toward higher transparency levels necessary for citizens' constructive participation in the budgetary process and control over the 
collection and spending of public funds. A summary of results for all counties, cities and municipalities is provided in the text below, while more detail is available in the form of an interactive map and an Excel table.

For several years now, the Institute of Public Finance has been conducting analyses of budget transparency in Croatian counties, cities and municipalities. The present article provides a summary of results of the latest analysis conducted in the periods NovemberDecember 2020 and February-April 2021. ${ }^{2}$

Budget transparency implies providing an insight into complete, accurate, timely and understandable information regarding the budget. This information enables citizens to participate and thus affect the efficiency of collection and spending of public funds, to demand more accountability from the Government and local government authorities ${ }^{3}$ and, consequently, to reduce potential acts of corruption.

${ }^{1}$ This note is an outcome of the project "Does Transparency Pay-off? The political and socio-economic impacts of local budget transparency in Croatia" (IP-2019-04-8360) financed by the Croatian Science Foundation (HRZZ). The work of postdoctoral researcher Marija Opačak is also financed by HRZZ. Opinions, findings, conclusions and recommendations are the authors' own and do not necessarily reflect the views of HRZZ. The authors are grateful to Filip Badovinac for his assistance with data collection.

${ }^{2}$ Results of previous research were published in Ott, Bronić and Petrušić (2013, 2014, 2015), Ott, Bronić, Petrušić and Stanić $(2016,2017,2018)$ and Ott, Bronić, Petrušić, Stanić and Prijaković (2019, 2020).

${ }^{3}$ Irrespective of the formal distinction between the units of local and regional self-government, for the purpose of this article, the term "local government units" covers all 20 counties, 128 cities and 428 municipalities. 
For the purpose of this study, budget transparency is measured as the number of key budget documents published on the official websites of Croatian local government units. ${ }^{4}$

They include the following:

- the 2019 year-end budget execution report;

- the 2020 mid-year budget execution report;

- $\quad$ the 2021 budget proposal;

- the 2021 enacted budget;

- $\quad$ the 2021 citizens' budget. ${ }^{5}$

The aim of the study was to establish the number of key budget documents published on the local government units' websites, without going into a detailed analysis of their contents. Naturally, there is always the possibility that the researchers were unable to find the needed documents on a website even though they had been published, but this would only mean that the citizens would also have difficulties finding the documents as they have not been displayed prominently enough. In addition, the mere publication of these five key documents does not necessarily imply absolute budget transparency of these local government units or absolute

\footnotetext{
${ }^{4}$ Principles of this research were described in detail in Ott, Bronić, Petrušić, Stanić and Prijaković (2020).

${ }^{5}$ In the period from 2 November to 31 December 2020, the authors examined whether the 2019 year-end and 2020 mid-year budget execution reports have been published, while from 15 February to 14 April 2021, they checked for the publication of 2021 budget proposals, enacted budgets and citizens' budgets. The present analysis only considers the documents available on the local government units' websites during the observed research periods and on the days the websites were searched. Subsequently published documents were not considered. On 14 October 2020, an e-mail was sent to all local government units, informing them of the time and manner in which their respective websites would be examined.
} 
accountability of their authorities with regard to the budget; rather, it merely serves as verification that they complied with the Budget Act, Act on the Right of Access to Information and the recommendations issued by the Ministry of Finance. ${ }^{6}$ This level of budget transparency can be considered only the first step toward greater budget transparency and the fundamental prerequisite for citizens to become acquainted with local budgets. Only citizens who are informed and knowledgeable about the budget are able to participate in local budgeting in a constructive manner, i.e., in making decisions on the collection and spending of local funds, as well as in supervising the accountability of local government authorities.

Over the previous seven research cycles, budget transparency of all local government units has grown from an average of 1.8 in the first cycle to 4.5 published documents as per the present cycle. All types of local government units show progress with regard to all budget documents, as evidenced by the publication of the citizens' budget - in 2015, this document was published by only $1 \%$ of municipalities; in 2020 this rate stands at 80\% (Graph 1).

${ }^{6}$ The legislative framework of budget transparency was described in Ott, Bronić, Petrušić, Stanić and Prijaković (2020). 


\section{Graph 1. Budget documents published, 2015-2021 (in \%)}

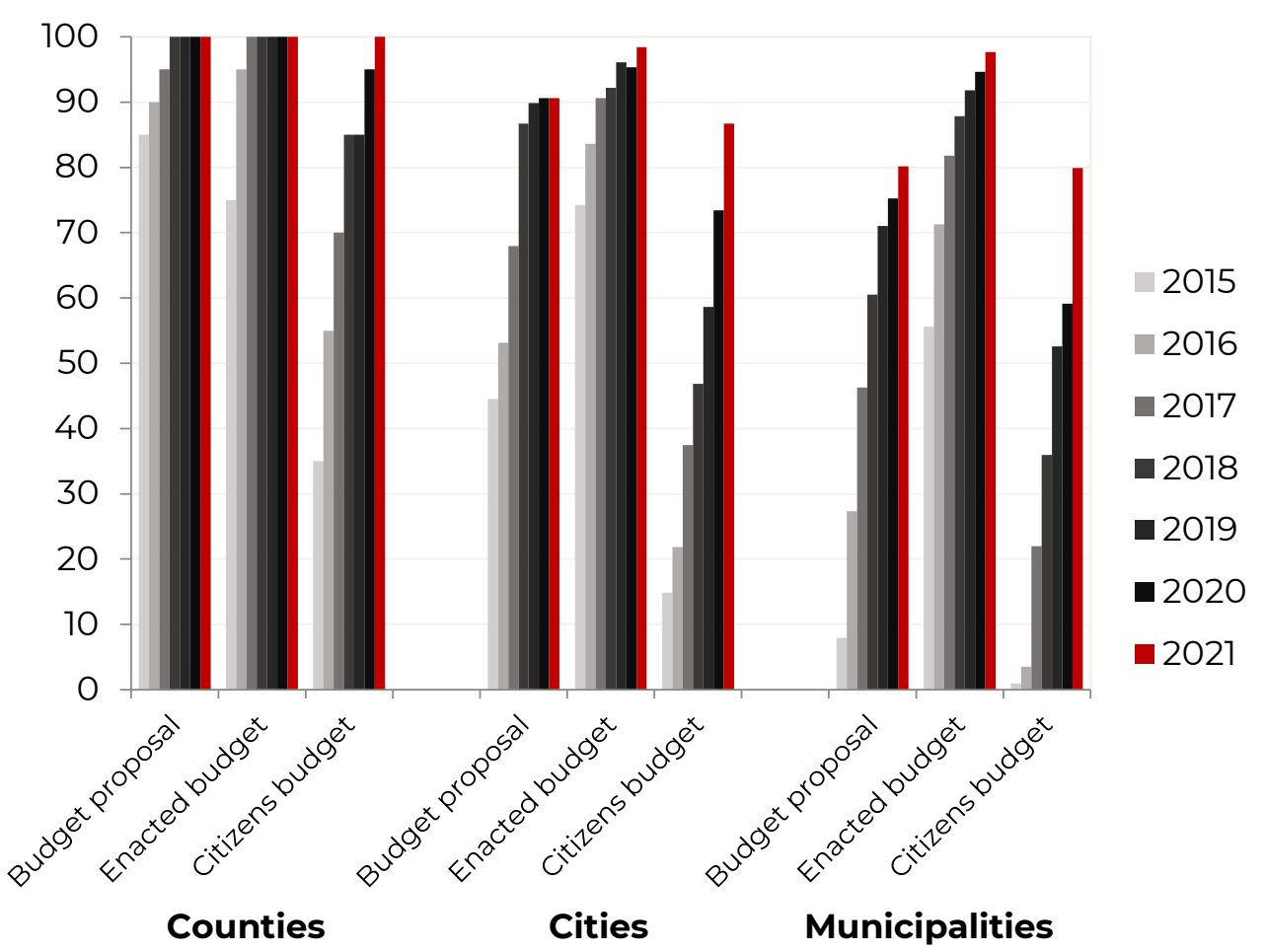

In the present cycle, all counties published all five budget documents, cities scored an average rate of 4.7, while municipalities' average score stands at 4.4 (Graphs 2 and 3). 
Graph 2. Budget transparency levels of local government units, November 2020-April 2021 (in \%)

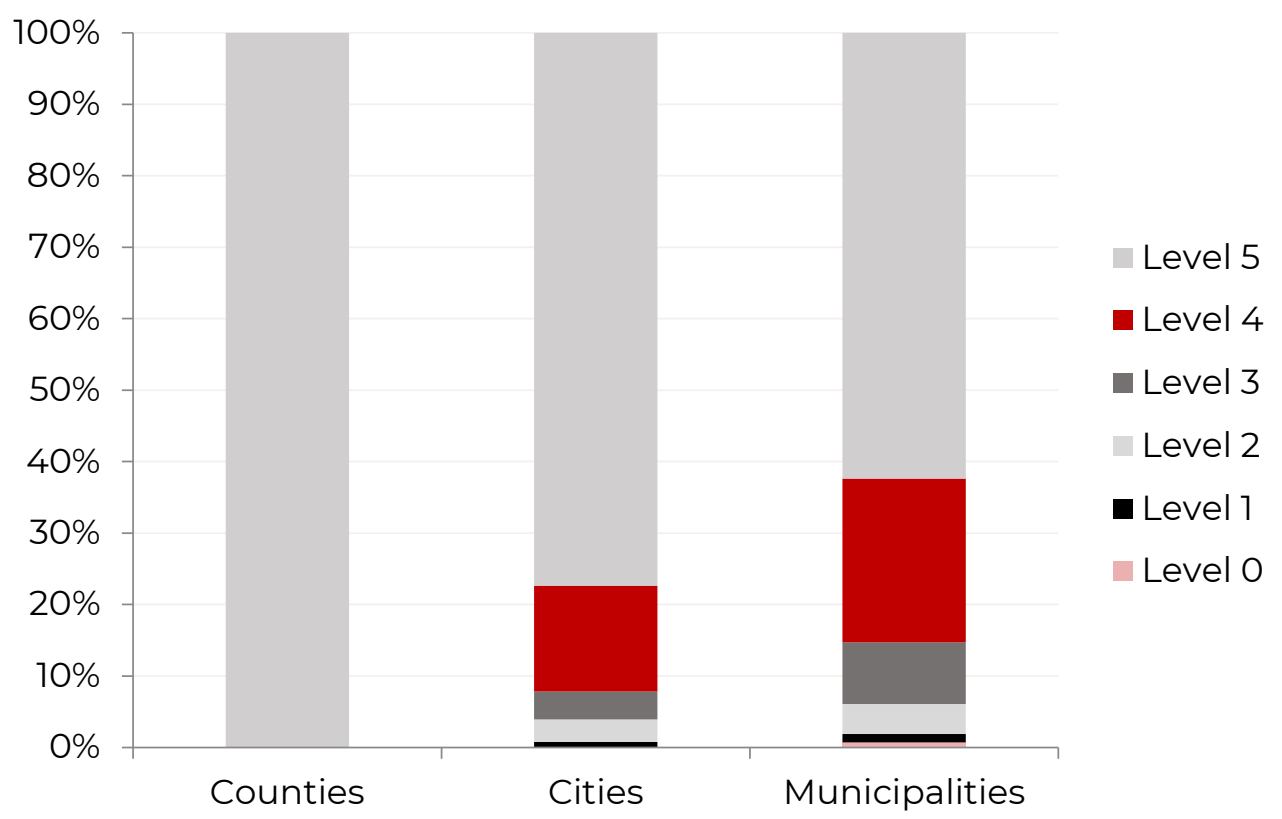

Graph 3. Budget documents published, November 2020-April 2021 (in \%)

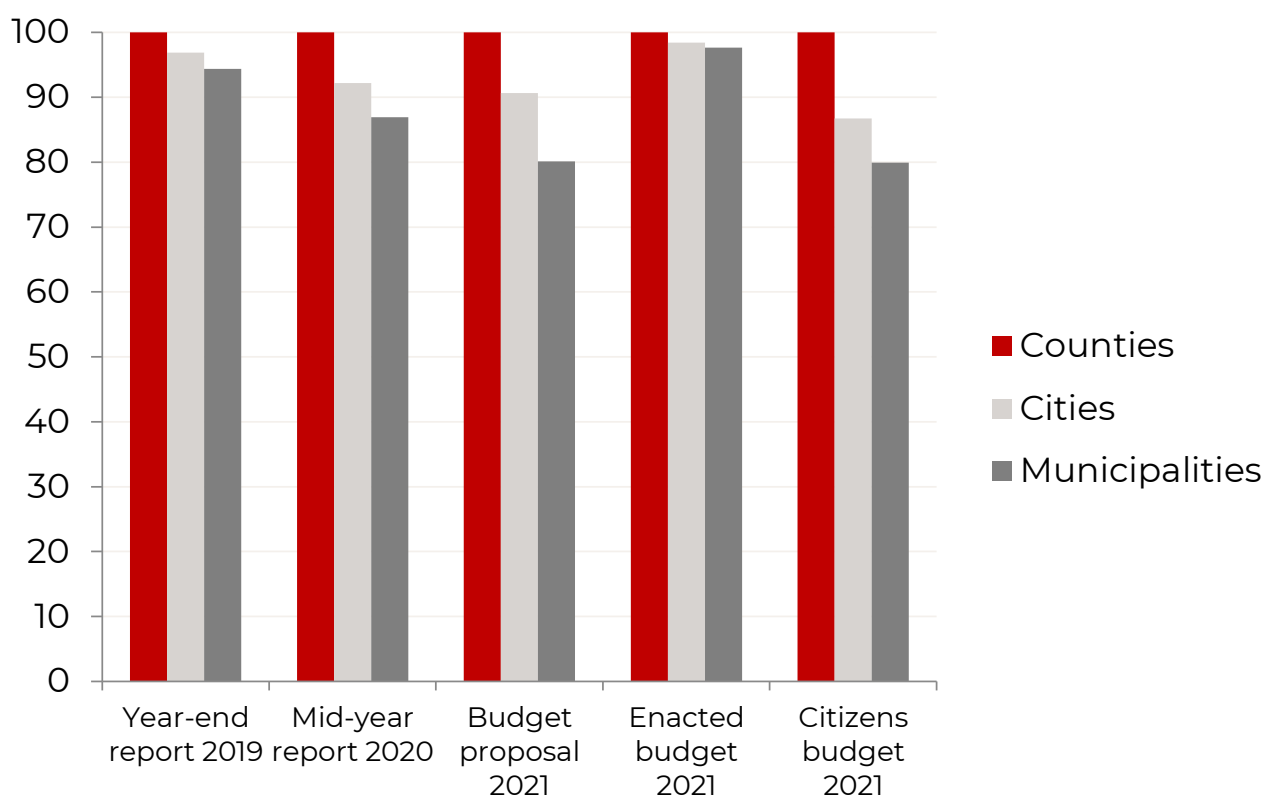


However, despite constant improvements, three municipalities failed to publish a single budget document in the present cycle concerned, whereas five municipalities and one city published only one such document each (Table 1). Moreover, $8 \%$ of cities and $16 \%$ of municipalities still fail to publish the three documents required by law (enacted budget, mid-year and year-end budget execution report). In addition, $20 \%$ of cities and $31 \%$ of municipalities ignored the Ministry of Finance's instructions to publish two additional documents (budget proposal and citizens' budget).

\section{Municipalities}

\section{Graph 4. Average transparency of municipalities and cities (by county)}

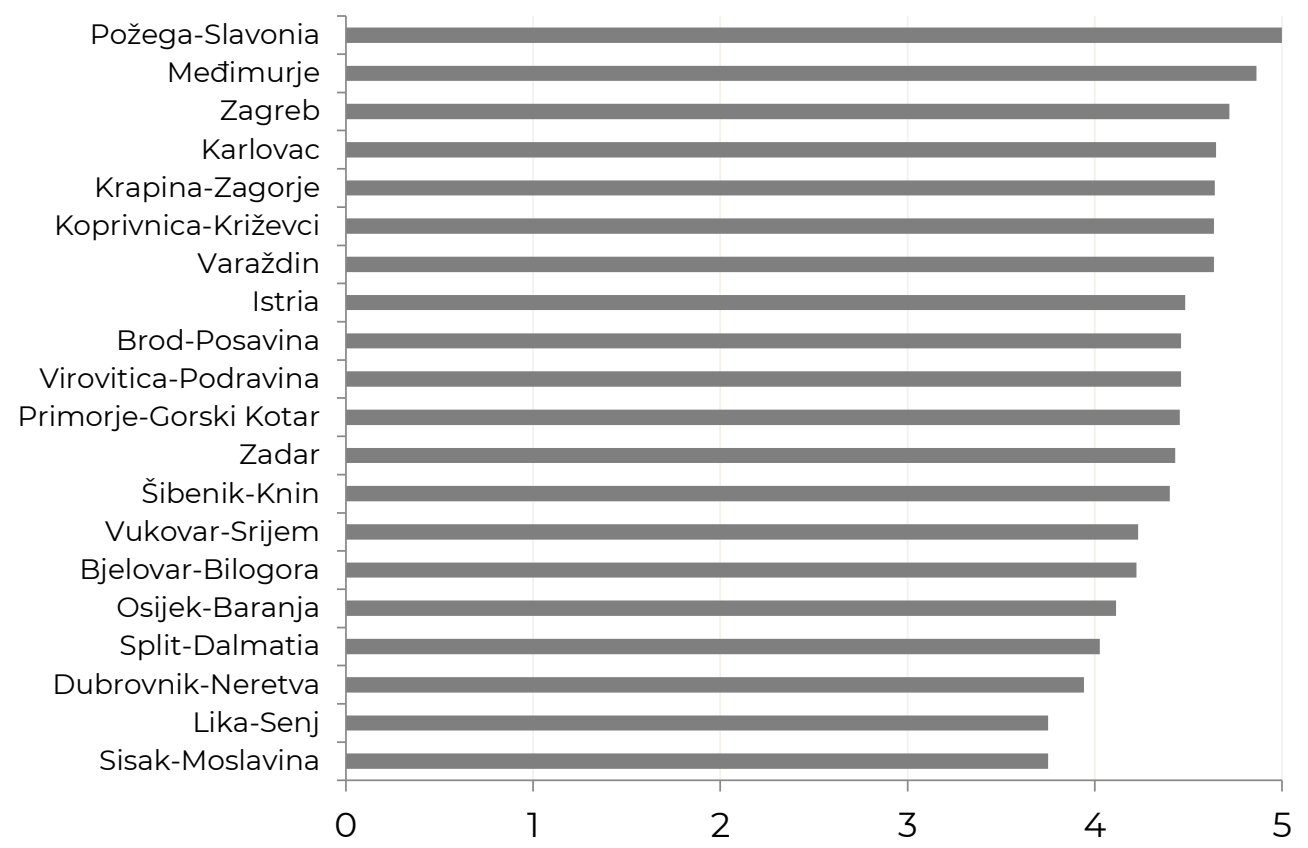




\section{Cities}

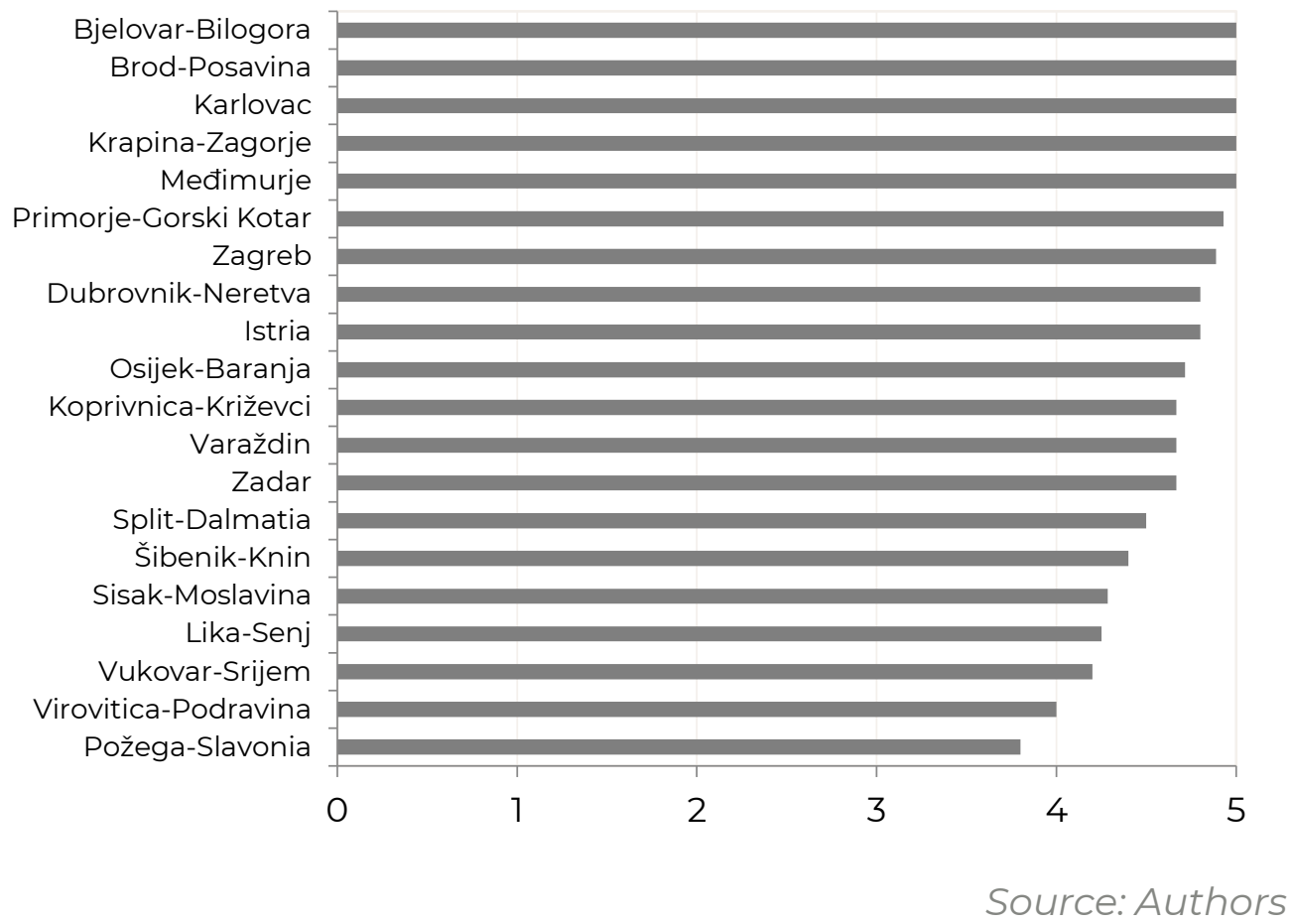

The fewest number of budget documents on average was published by municipalities in the Sisak-Moslavina and Lika-Senj counties (3.8 out of 5). All municipalities in the Požega-Slavonia County published all five key budget documents. However, the Požega-Slavonia County also holds one negative record as the cities in this county published the fewest average number of documents (3.8), while in five counties all cities published all five documents (Bjelovar-Bilogora, Brod-Posavina, Karlovac, Krapina-Zagorje and Međimurje) (Graph 4).

The leading counties with regard to average budget transparency for all local government units in their territory are Međimurje, Zagreb, Karlovac and Krapina-Zagorje counties, while the bottom positions are occupied by Sisak-Moslavina, Lika-Senj, DubrovnikNeretva and Split-Dalmatia counties (Graph 5). 


\section{Graph 5. Overall average transparency of counties*}

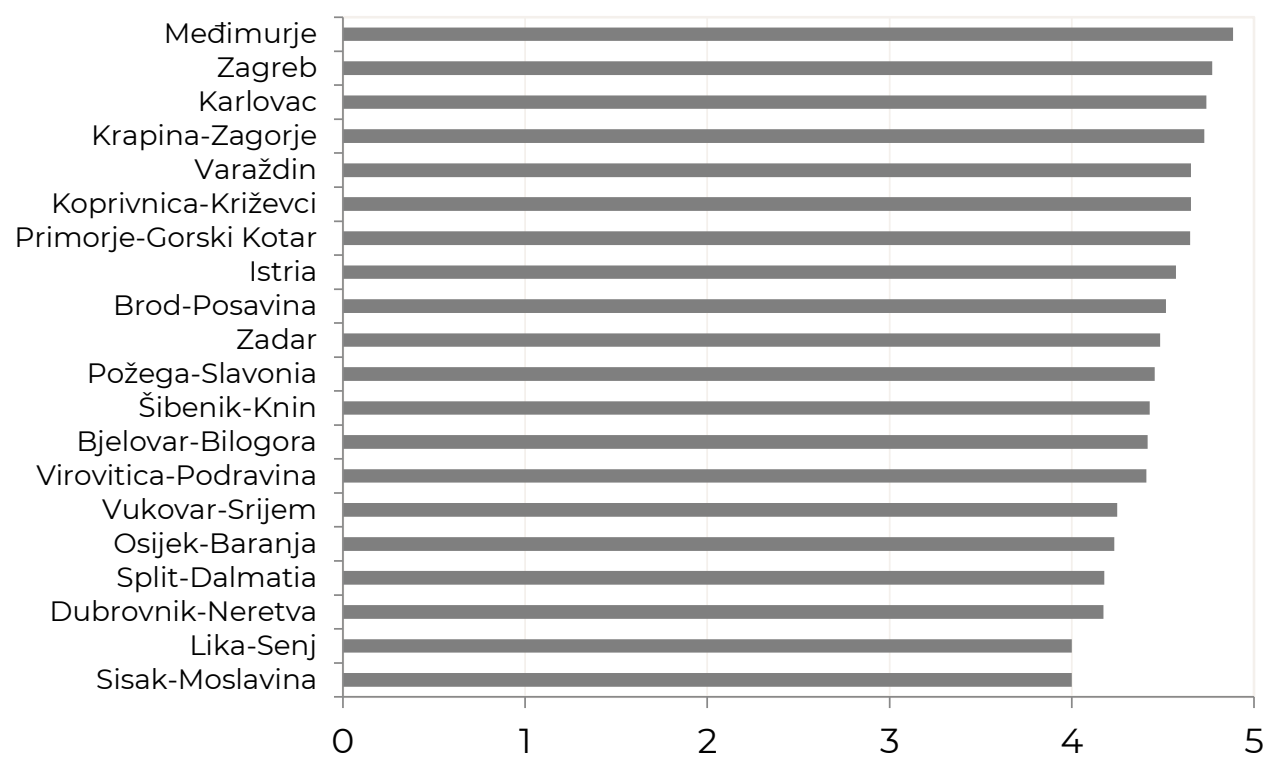

* Calculated as the sum of transparency for a given county and all cities and municipalities located therein, divided by the total number of local government units in that county, including the county itself.

Compared to the previous research cycle, $11 \%$ of units published fewer documents (one or two fewer documents on average, with the City of Pakrac and Višnjan municipality publishing three documents less). What is encouraging is the fact that $30 \%$ of all units published more documents than in the previous cycle (Galovac municipality jumped from zero to five, while another eight municipalities published four documents more than in the previous cycle - Bogdanovci, Donja Voća, Gorjani, Kolan, Lanišće, Lovreć, Sveti Filip i Jakov, and Vrbje).

More detailed results on budget transparency for all counties, cities and municipalities are available in the form of an interactive map 
and an Excel table. In addition, our previous analyses of budget transparency ${ }^{7}$ provide conclusions and recommendations that might serve the purpose of both improving budget transparency and laying the foundations for potential reform of the fiscal and territorial arrangement of the country.

Table 1. Budget transparency levels of counties, cities and municipalities (by number of published documents, in alphabetical order)

\begin{tabular}{|c|c|c|}
\hline \multicolumn{2}{|c|}{$\begin{array}{c}\text { LEVEL OF } \\
\text { TRANSPARENCY }\end{array}$} & LOCAL UNITS \\
\hline \multirow{3}{*}{5} & COUNTIES & $\begin{array}{c}\text { Bjelovar-Bilogora, Brod-Posavina, Dubrovnik-Neretva, } \\
\text { Istria, Karlovac, Koprivnica-Križevci, Krapina-Zagorje, Lika- } \\
\text { Senj, Međimurje, Osijek-Baranja, Požega-Slavonia, } \\
\text { Primorje-Gorski Kotar, Sisak-Moslavina, Split-Dalmatia, } \\
\text { Šibenik-Knin, Varaždin, Virovitica-Podravina, Vukovar- } \\
\text { Srijem, Zadar, Zagreb }\end{array}$ \\
\hline & CITIES & $\begin{array}{l}\text { Bakar, Beli Manastir, Belišće, Benkovac, Bjelovar, Buzet, } \\
\text { Cres, Crikvenica, Čabar, Čakovec, Čazma, Daruvar, } \\
\text { Delnice, Donja Stubica, Drniš, Dubrovnik, Duga Resa, } \\
\text { Dugo Selo, Đakovo, Đurđevac, Garešnica, Glina, Gospić, } \\
\text { Grubišno Polje, Hvar, Imotski, Ivanec, Ivanić-Grad, } \\
\text { Jastrebarsko, Karlovac, Kastav, Kaštela, Klanjec, Komiža, } \\
\text { Koprivnica, Korčula, Kraljevica, Krapina, Krk, Kutina, Labin, } \\
\text { Lepoglava, Lipik, Ludbreg, Makarska, Mali Lošinj, } \\
\text { Metković, Mursko Središće, Našice, Nin, Nova Gradiška, } \\
\text { Novalja, Novigrad, Novska, Ogulin, Opatija, Oroslavje, } \\
\text { Osijek, Otok, Ozalj, Pag, Pazin, Pleternica, Ploče, } \\
\text { Popovača, Poreč, Požega, Pregrada, Prelog, Pula, Rab, } \\
\text { Rijeka, Rovinj, Samobor, Sinj, Sisak, Slavonski Brod, Slunj, } \\
\text { Split, Supetar, Sveta Nedelja, Sveti Ivan Zelina, Šibenik, } \\
\text { Trogir, Umag, Varaždin, Varaždinske Toplice, Vinkovci, } \\
\text { Virovitica, Vodice, Vrbovec, Vrbovsko, Vrgorac, Vukovar, } \\
\text { Zabok, Zadar, Zagreb, Zaprešić, Zlatar }\end{array}$ \\
\hline & MUNICIPALITIES & $\begin{array}{l}\text { Andrijaševci, Antunovac, Babina Greda, Bale, Barban, } \\
\text { Baška, Baška Voda, Bebrina, Bedekovčina, Bedenica, } \\
\text { Bednja, Belica, Beretinec, Bibinje, Biskupija, Bistra, Blato, } \\
\text { Bogdanovci, Bosiljevo, Bošnjaci, Brckovljani, Brdovec, } \\
\text { Brela, Brestovac, Breznica, Brtonigla, Budinščina, } \\
\text { Bukovlje, Cerna, Cernik, Cestica, Cetingrad, Crnac, Čačinci, } \\
\text { Čaglin, Čavle, Čepin, Davor, Dekanovec, Desinić, Dobrinj, } \\
\text { Domašinec, Donja Dubrava, Donja Voća, Donji Andrijevci, }\end{array}$ \\
\hline
\end{tabular}

7 See: Ott et al (2019). 


\begin{tabular}{|c|c|c|}
\hline 5 & & 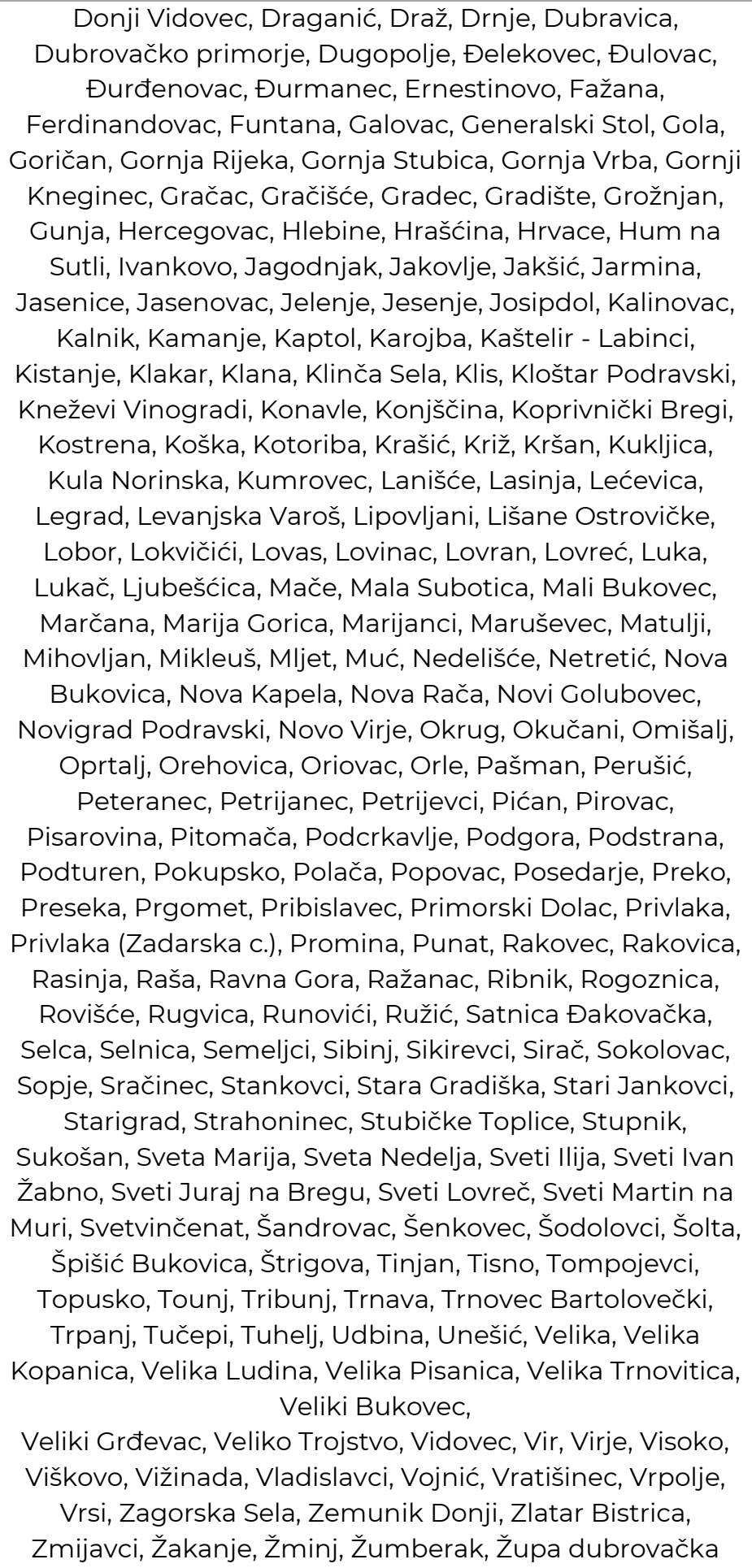 \\
\hline 4 & CITIES & $\begin{array}{c}\text { Biograd na Moru, Buje, Donji Miholjac, Ilok, Križevci, Novi } \\
\text { Vinodolski, Obrovac, Opuzen, Orahovica, Petrinja, Senj, } \\
\text { Skradin, Solin, Stari Grad, Valpovo, Velika Gorica, Vis, } \\
\text { Vodnjan, Vrlika }\end{array}$ \\
\hline
\end{tabular}




\begin{tabular}{|c|c|c|}
\hline 4 & MUNICIPALITIES & $\begin{array}{l}\text { Barilović, Berek, Bilice, Bilje, Bizovac, Bol, Brinje, Brodski } \\
\text { Stupnik, Cerovlje, Cista Provo, Civljane, Čađavica, Darda, } \\
\text { Dežanovac, Dicmo, Donja Motičina, Dragalić, Drenovci, } \\
\text { Dubrava, Dugi Rat, Farkaševac, Fužine, Gorjani, Gornji } \\
\text { Mihaljevec, Hrvatska Dubica, Jalžabet, Kali, Kanfanar, } \\
\text { Kloštar Ivanić, Kolan, Končanica, Koprivnički Ivanec, } \\
\text { Krapinske Toplice, Krnjak, Ližnjan, Lokve, Lopar, } \\
\text { Lumbarda, Lupoglav, Magadenovac, Malinska-Dubašnica, } \\
\text { Marija Bistrica, Markušica, Martijanec, Martinska Ves, } \\
\text { Medulin, Milna, Molve, Mošćenička Draga, Motovun, } \\
\text { Murter, Novigrad, Nuštar, Oprisavci, Orebić, Petlovac, } \\
\text { Plitvička Jezera, Podgorač, Podravske Sesvete, Poličnik, } \\
\text { Postira, Primošten, Pučišća, Radoboj, Rešetari, Sali, Seget, } \\
\text { Skrad, Slavonski Šamac, Smokvica, Ston, Strizivojna, } \\
\text { Suhopolje, Sunja, Sutivan, Sveti Đurđ, Sveti Filip i Jakov, } \\
\text { Sveti Križ Začretje, Škabrnja, Štefanje, Tar-Vabriga, Tkon, } \\
\text { Tovarnik, Trpinja, Vela Luka, Veliko Trgovišće, Vinica, } \\
\text { Vinodolska općina, Viškovci, Voćin, Vrbanja, Vrbje, Vrbnik, } \\
\text { Vrhovine, Vuka, Zadvarje, Zagvozd, Zažablje }\end{array}$ \\
\hline & CITIES & Knin, Novi Marof, Omiš, Otočac, Slatina, Trilj \\
\hline 3 & MUNICIPALITIES & $\begin{array}{l}\text { Borovo, Breznički Hum, Brod Moravice, Donji Kraljevec, } \\
\text { Donji Kukuruzari, Ervenik, Feričanci, Garčin, Gornji } \\
\text { Bogićevci, Gradac, Gradina, Gundinci, Gvozd, Ivanska, } \\
\text { Jelsa, Kapela, Klenovnik, Kraljevec na Sutli, Kravarsko, } \\
\text { Lastovo, Majur, Marina, Mrkopalj, Negoslavci, Nijemci, } \\
\text { Petrovsko, Plaški, Podravska Moslavina, Pušća, Saborsko, } \\
\text { Stari Mikanovci, Staro Petrovo Selo, Sveti Petar u Šumi, } \\
\text { Štitar, Tordinci, Vođinci, Zdenci }\end{array}$ \\
\hline \multirow[b]{2}{*}{2} & CITIES & Kutjevo, Pakrac, Županja \\
\hline & MUNICIPALITIES & $\begin{array}{l}\text { Čeminac, Drenje, Dvor, Erdut, Janjina, Karlobag, Kijevo, } \\
\text { Lekenik, Otok, Pakoštane, Podbablje, Proložac, Severin, } \\
\text { Slivno, Sućuraj, Viljevo, Vrsar, Zrinski Topolovac }\end{array}$ \\
\hline \multirow{2}{*}{1} & CITIES & Hrvatska Kostajnica \\
\hline & MUNICIPALITIES & Donji Lapac, Pojezerje, Punitovci, Šestanovac, Višnjan \\
\hline $\mathbf{0}$ & MUNICIPALITIES & Nerežišća, Povljana, Sveti Petar Orehovec \\
\hline
\end{tabular}

